\title{
4. Roadmap to innovation and skill-based cluster ecology development initiatives
}

Policy and investment recommendations depend on the Asian regions' geographies, resource profiles, technology profiles, production and trade structures, and institutional frameworks (OECD, 2011, 2013). Regions differ, for instance, in the central, urban and non-central, industrial- and agriculture-based set-up in Asia. As we have indicated in Chapter 3, the GMS is prone to a central, urban character in its innovation cluster set-up. In contrast, CAREC countries have a more non-central, industrial- and agriculture-based character, with quite different policy and investment implications. This chapter will specify and elaborate on these, especially for the GMS, and features a short section on CAREC.

This chapter draws on the lessons from the BSR that are related to the GMS context. It then outlines innovation-cluster-ecology-directed development initiatives using degrees of proximity, embeddedness, and connectivity across the GMS, as examined in the preceding analysis. Regional institutional frameworks embed innovation cluster ecologies in collaborative networks and in relationships between firms and all other innovation actors. Actions in those three categories relate to policy instruments (labor market, skill development, FDI technology, corridor and cluster development, innovation and competition; see Figure 1.1), and related to RCI drivers of welfare impact as in Figure 1.1. BSRinspired toolboxes (refer to Figure 2.12), which catalyze connection (embeddedness), create bridges (connectivity), and strengthen intraregional flows (proximity) will be proposed and outlined for the GMS context. To make policy action sustainable, it is essential to formulate metrics that make achievements visible. Special emphasis is on the need to introduce and use an Asian Regional Economic Integration Observatory (AREIO). Thus, this chapter outlines a plan for an AREIO by drawing on the details of other chapters in this book. From this, an initial roadmap can emerge. 


\section{INNOVATION AND SKILL-BASED CLUSTER ECOLOGY DEVELOPMENT IN CENTRAL, URBAN REGIONS OF THE GREATER MEKONG SUBREGION}

Given that the GMS can be characterized as a central, urban region in terms of its innovation cluster ecology set-up (as indicated in the previous chapters and as visualized in the respective maps), it typically faces issues related to agglomeration spillover effects and to structure transformation. One such issue is the inadequacy of the skills profile - apparent, for example, in Thailand and Viet Nam - to generate higher value-added trade shares in GVCs, and to better exploit open regionalism for economies of scale, and for backward (intraregion) linkages. In the GMS, innovation cluster development is devoid of economies of scale. Only a larger scale of regional activities will support the requisite hard and soft infrastructure, together with mediating institutional (formal and informal) structures necessary. If the labor skill profile cannot be adapted to an ever more competitive global environment, it will increasingly lead to a bimodal income distribution dominated by high skills for a few in central urban agglomerations, and by a large number of low wage groups at the other end of the distribution. Regional action in this type of region needs to focus on tools and drivers of productivity and welfare by supporting spillover effects and structure transformation through catalyzing knowledge connections in a network of emerging innovation clusters (cluster ecology).

\subsection{Embeddedness and Connectivity}

Clusters evolve and are embedded in specific geographic (regional), sociocultural and regulatory and institutional environments (World Bank, 2010, p. 319). The evolution of the BSR cooperation and collaboration institutions, formal and informal, is instructive (see Figure 2.13 and Table 4.1, for an overview).

\section{What roles need to be played by formal governance structures, and informal} innovation policy and capacity-building structures?

The BSR set up a decision forum at the ministerial level, the Baltic Development Forum, very similar to the GMS ministerial meetings. At this level, decision-making is not entirely focused on productivity-enhancing policy instruments and related tools aimed at inclusive growth drivers. Rather, the BDF is a network for high-level decision makers from business, government, academia and other civil society (triple helix). As such, BDF provides a platform for all interested regional stakeholders. It is more 
Table 4.1 Roadmap of Baltic Sea Region cooperation and integration efforts in innovation clusters

\begin{tabular}{|c|c|c|c|c|c|c|c|}
\hline & 1990 & 1995 & 2000 & 2005 & & 2010 & 2015 \\
\hline $\begin{array}{l}\text { Regional } \\
\text { Integration } \\
\text { Policies } \\
\text { Catalyze } \\
\text { Connections }\end{array}$ & & & $\begin{array}{l}\text { Baltic } \\
\text { Develop- } \\
\text { ment } \\
\text { Forum } \\
(1998)\end{array}$ & $\begin{array}{l}\text { ECO } \\
(2004)\end{array}$ & $\begin{array}{l}\text { ESPON } \\
(2006)\end{array}$ & $\begin{array}{l}\text { ECEI } \\
\text { (2009) }\end{array}$ & $\begin{array}{l}\text { PA INNO } \\
\text { Stg } \\
\text { Committee } \\
(2014)\end{array}$ \\
\hline $\begin{array}{l}\text { Create } \\
\text { Bridges }\end{array}$ & & & & & \multicolumn{3}{|c|}{$\begin{array}{l}\text { BSR Stars } \\
(2010)\end{array}$} \\
\hline $\begin{array}{l}\text { Strengthen } \\
\text { Flows }\end{array}$ & \multicolumn{2}{|c|}{$\begin{array}{l}\text { Baltic } \\
\text { University } \\
\text { Programme } \\
\text { (1991) }\end{array}$} & & & \multicolumn{3}{|c|}{$\begin{array}{l}\text { BONUS } \\
\text { Research and } \\
\text { Innovation } \\
\text { Programme } \\
(2009)\end{array}$} \\
\hline
\end{tabular}

Notes: $\quad$ BONUS $=$ Joint Baltic Sea Research and Development Program; BSR $=$ Baltic Sea Region; ECEI = European Cluster Excellence Initiative; ECO = European Cluster Observatory; ESPON = European Observation Network for Territorial Development and Cohesion; PA INNO = Priority Area Innovation.

Source: Ketels and Wise (2015).

evidence based in its policy-making agenda than seems the case in the GMS, as it has various knowledge tools at its disposal (ECO, ESPON) which enable prioritization, key success indicator measurement and monitoring on a comprehensive regional and continuing basis. The BDF offers a neutral ('trustworthy, honest broker') platform, as does ADB in the GMS case, for catalyzing and facilitating cooperation and collaboration throughout the region.

Regional trust creation takes time and effort, especially in regions with a set of differing histories, clusters, practices and languages. This has been apparent from field surveys, where key stakeholders emphasized the need for trusted, neutral brokers, such as ADB, in forging a regional narrative rooted in common histories. In the case of Asian regions, the silk road narrative could function as such a unifier, supported by formal and informal cooperation and integration institutions, which use evidence-based and consensual decision-making processes.

In the BSR example, the trustworthy informal meeting and decisionmaking structure, which focuses on innovation-related policies and 
tools - their prioritization, deployment and implementation, as well as the monitoring of their impact - is the Innovation Screening Committee (PA INNO). PA INNO catalyzes connections among clusters and networks (see Figure 2.12). BSR Stars aims to strengthen competitiveness and economic growth in the Baltic Sea Region by fostering regional, transnational linkages between specialized research and innovation nodes, leading to new types of collaboration that can deliver new products, services and business models for global markets. ${ }^{1}$

Foremost needed in the GMS is the establishment of a regional coordinator (secretariat) of cluster-network-based cooperation. Such a coordination arrangement can be housed in a critical innovation hub of the GMS. The coordinator will act as facilitator, creating and maintaining connection with the public sector, the business community, and the non-profit education and research sectors (triple helix), and the international networks in the related products and fields. Under the coordinator structure, priority innovation steering groups could be chaired by representatives from different countries, according to national priorities. The kinds of instruments and tools that can be employed in the GMS context are platforms and tools for dialogue and networking between triple helix cluster stakeholders, including construction of actual and virtual meeting spaces, creation of knowledge-enhancing partnerships and twinning arrangements (such as under the proposed AREIO), and building of comparable innovation cluster statistics and data anchored in geography (GIS-compatible).

The ESPON 2013 database provides fundamental regional information provided by ESPON projects and EUROSTAT. This information can be used to support territorial development analysis at different geographical levels. The database aims to contribute to a better understanding of the potentials and development perspectives of regions in the European context and globalized world as its comparable data makes benchmarking of regions and cities feasible. There is no comparable regional data and knowledge platform in Asia.

The heterogeneity of experience and capacity that exists among GMS member states requires that certain higher capacity countries or provinces take stronger leadership responsibilities. At all levels of governance, a strong, cross-cultural and cross-linguistic and inspirational core of leadership (comprised of at least two countries' representatives) is key.

This is demonstrated by BSR Stars, one of the priority areas under PA INNO. The mission of BSR Stars is to shape a more integrated and dynamic resource base for innovation clusters by stimulating flows among research environments, clusters and SME networks. Similar to the BSR Stars' body of expertise, the GMS requires an expert body that can fund and implement types of collaboration in the emerging cluster 
ecology. It needs to build 'bridges', which translate into regional cluster connectivity.

The ECEI aims to develop management capacities in cluster organizations. From fieldwork in the GMS, it is clear that such an initiative would be very welcome in the region. It would catalyze a viable cluster ecology, ultimately strengthening firm-level productivity in the region. This could be one of the initiatives taken up by the regional coordinator.

\subsection{Proximity}

In the BSR experience, the Baltic University Program aims at strengthening East-West collaboration among universities through the joint development of courses, degrees and support to student mobility. A basic idea of the program is to foster intercultural understanding by student groups undertaking research together. BONUS is a BSR-level program that supports collaborative research projects focused on sustainable development. BONUS members are the national research funding institutions. These tools are aimed at strengthening the flow of people, ideas and collaborative development. Similar programs focused on innovation clusters can be instituted in Asian regions. An informal arrangement among national research funding institutions could be crafted. Institutions that have high research capacity and are advanced technically can twin with the lagging nations' institutions in regional projects. It is important to enhance the skilled-labor flows, for instance, in GMS. Such programs should involve the triple helix.

The lack of intraregion innovation cluster proximity (that is, intraregion knowledge linkages of innovation cluster investments) can guide a policy and investment roadmap that makes use of agglomeration spillovers and structural transformation. Figure 4.1 provides an overview of policy instruments affecting key regional drivers.

\section{What kind of instruments and tools contribute to productivity growth from cluster and corridor development initiatives?}

On a regional basis, coordinated among a network of clusters, governments and businesses should establish innovation service platforms (public-private). Innovation clusters are well suited to harbor the regional connections that enable knowledge flows. These platforms are conceived broadly, for instance, encompassing science and technology literature access, technology transfer enhancements, standard and quality testing cooperation, and scientific equipment sharing.

The emphasis will be particularly strong for SMEs. For instance, technology platforms can link technical and vocational schools and SMEs. Technology transfer centers in a relevant sector can be co-founded by 


\begin{tabular}{|c|c|c|c|}
\hline $\begin{array}{c}\text { POLICY } \\
\text { INSTRUMENT }\end{array}$ & TOOL BOX & DRIVER & $\begin{array}{l}\text { WELFARE } \\
\text { IMPACT }\end{array}$ \\
\hline $\begin{array}{l}\text { Regional Innovation Coordinator } \\
\text { (Secretariat) }\end{array}$ & Structure & $\begin{array}{l}\text { Structure } \\
\text { Transformation }\end{array}$ & Competitiveness \\
\hline $\begin{array}{l}\text { Priority innovation steering } \\
\text { groups }\end{array}$ & Mobility & Agglomeration & $\begin{array}{l}\text { Productivity + } \\
\text { Distribution }\end{array}$ \\
\hline Intra-regional cluster support & Mobility & Agglomeration & $\begin{array}{l}\text { Productivity + } \\
\text { Distribution }\end{array}$ \\
\hline Innovation vouchers & Mobility & Agglomeration & $\begin{array}{l}\text { Productivity + } \\
\text { Cohesion }\end{array}$ \\
\hline $\begin{array}{l}\text { Innovation awareness raising } \\
\text { events }\end{array}$ & Mobility & Agglomeration & $\begin{array}{l}\text { Productivity + } \\
\text { Cohesion }\end{array}$ \\
\hline $\begin{array}{l}\text { Regional benchmarking data } \\
\text { platform }\end{array}$ & Analysis & Agglomeration & $\begin{array}{l}\text { Productivity + } \\
\text { Cohesion }\end{array}$ \\
\hline $\begin{array}{l}\text { Asian Regional Economic } \\
\text { Integration Observatory (AREIO) }\end{array}$ & $\begin{array}{l}\text { Analysis/ } \\
\text { Research }\end{array}$ & $\begin{array}{l}\text { Structure } \\
\text { Transformation }\end{array}$ & Competitiveness \\
\hline
\end{tabular}

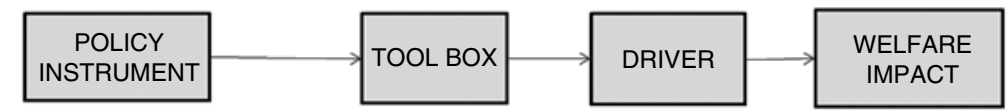

\begin{tabular}{|l|l|l|l|}
\hline $\begin{array}{l}\text { Technical university } \\
\text { collaboration programs }\end{array}$ & Research, Analysis & $\begin{array}{l}\text { Structure } \\
\text { Transformation }\end{array}$ & Competitiveness \\
\hline $\begin{array}{l}\text { Technology platforms } \\
\text { linking technical schools } \\
\text { and SMEs }\end{array}$ & Analysis & $\begin{array}{l}\text { Human Capital } \\
\text { Intensity }\end{array}$ & Competitiveness \\
\hline $\begin{array}{l}\text { Technology transfer } \\
\text { centers (PPP) }\end{array}$ & Analysis & $\begin{array}{l}\text { Structure } \\
\text { Transformation }\end{array}$ & Competitiveness \\
\hline Branded excellence hubs & Structure & $\begin{array}{l}\text { Structure } \\
\text { Transformation }\end{array}$ & $\begin{array}{l}\text { Productivity + } \\
\text { Cohesion }\end{array}$ \\
\hline $\begin{array}{l}\text { Vocational training for low- } \\
\text { skilled and unemployed }\end{array}$ & Mobility & Agglomeration & $\begin{array}{l}\text { Productivity + } \\
\text { Distribution }\end{array}$ \\
\hline $\begin{array}{l}\text { Connecting SMEs with } \\
\text { export finance, insurance }\end{array}$ & Mobility & Agglomeration & $\begin{array}{l}\text { Productivity + } \\
\text { Cohesion }\end{array}$ \\
\hline $\begin{array}{l}\text { Capacity building platform } \\
\text { for cluster management }\end{array}$ & Structure & $\begin{array}{l}\text { Structure } \\
\text { Transformation }\end{array}$ & $\begin{array}{l}\text { Productivity + } \\
\text { Cohesion }\end{array}$ \\
\hline
\end{tabular}

Note: $\quad$ PPPs $=$ public - private partnerships; SMEs $=$ small- and medium-sized enterprises.

Source: Author.

Figure 4.1 New Asian regionalism: Greater Mekong Subregion to productivity and welfare 
governments in a public-private partnership set-up. One effective way of administering a public service platform is to issue 'knowledge vouchers' to SMEs for their usage. The knowledge voucher is a coupon that entitles eligible firms in a regional cluster network to a number of free services from exchange platforms, observatories, common research, and vocational technical training institutions. In 2009, a similar scheme was set up in Singapore to encourage SMEs to create new growth opportunities (OECD, 2011, p. 248). Introduction of innovation vouchers allow SMEs to vote for those services offered in a service menu of innovation platforms that promise the highest productivity effects for firms. The KHIDZ in Kunming is in the process of establishing a good part of this soft and hard infrastructure; however, this is not generally the case across the GMS.

Benchmarking instruments and platforms to global quality standards plays an important role in securing the success of such arrangements. Here, the role of an AREIO is critical, as further detailed below.

\section{CLUSTER ECOLOGY DEVELOPMENT IN NON-CENTRAL INDUSTRIAL AND AGRICULTURE-BASED REGIONS}

Non-central and agriculture-based regions do not exhibit highly dispersed systems focused on very large urban and core geographies. Such noncentral areas also exist in the GMS (that is, Lao PDR) and even more so in other Asian regions, for instance, CAREC. In this case, a policy and investment focus will be on specific local and interregional network-building. FDI and technology policies will have high priority in this context. Such areas can be important transit regions with logistics and production hubs using information and communication technology (ICT)-based systems. A program developing 'branded excellence logistics hubs' by international standards could be given high priority funding.

Furthermore, building interregional proximity is critical. This can be implemented by enhancing interregional and cluster flows of resources. The greater the local and regional multiplier effects of these demandoriented efforts are, the greater is the embeddedness of the overall regional system. Specialized skill training will focus on local demands. However, this will be most beneficial if done in a regional network approach, comprising vocational training programs in cluster skill centers.

Due to difficult access, CAREC-related field work was limited in PRC, Xinjian Province (Urumqi) and in Kazakhstan (Almaty). The special economic zone (SEZ) 'Innovation Technologies Park' is located in an Alatau 
village $20-25 \mathrm{~km}$ away from Almaty. The key objective of this innovation zone is to diversify sectors, which is crucial to Kazakhstan's overall economic diversification.

As company representatives pointed out, one of the difficulties is the relative remoteness of the SEZ from Almaty. Some of the companies keep their offices in the SEZ, but actually work in Almaty. This may indicate that companies stay, nominally, in the SEZ just to stay in the loop, communicate with other companies, and monitor opportunities that may emerge. Still, companies that are active in the SEZ reported success in their activities and the fact that the infrastructure, taxes and regulations within the SEZ are attractive for them. Nevertheless, they also indicated high logistics and transport costs as regards equipment delivery, import and so on. Overall, the companies that are based in the SEZ are poorly represented in global value chains and hardly export abroad at all. In addition, serious market knowledge gaps exist.

As for forthcoming development plans, the Kazakh Institute of Oil and Gas seeks to establish a scientific research center in the SEZ. Kazakhtelekom (the major telecommunications company) plans to establish a special data center that would store and process huge amounts of data used by the company. Kazakh-British Technical University (Almaty) and International University of Information Technologies (Almaty) plan to build their campuses there.

Instruments for benchmarking and platforms to global quality standards play as important a role in non-central, industrial and agricultural regions as they do in central, urban ones. The need for an AREIO extends to CAREC.

\section{WHAT INDICATORS IN CLUSTER DEVELOPMENT INITIATIVES CAN/SHOULD BE USED BY AN ASIAN REGIONAL ECONOMIC INTEGRATION OBSERVATORY? WHAT GOVERNANCE STRUCTURES SHOULD BE IN PLACE TO MAINTAIN OBSERVATORY OPERATION?}

For the roadmaps to be implementable, it is important that knowledge platforms for prioritization, monitoring, sharing and learning are developed. In the case of building innovation cluster ecologies, which, by its very nature, requires experimentation, it is even more important than in other cases of policy and investment to observe what works and what does not. Hence the need for an AREIO. 
The ECO in the BSR has been developed over time through a series of European grants. The current grant project is updating open data, maps of innovation cluster networks, and related indicators. Data for a regional competitiveness and inclusive growth analytical frame is linked to indicators of resource fundamentals, drivers and outcomes. The Stockholm School of Economics is assigned as the content manager to ensure sustainability and accessibility of ECO. Appendix 2 details the European ECO experience. In Asia, significantly better open data, indicators and analysis platforms for regions need to be developed to allow triple helix stakeholders to develop an objective and detailed understanding of regional integration assets and constraints, as well as of distribution of benefits and costs. Multilevel governance arrangements (local, national, regional) need to be continuously informed about developments in the regional productivity and income distribution landscapes. This requires static and dynamic data analysis on a regionally standardized basis. Very importantly, Asian regions need to institute a site content manager who ensures the quality of a trusted web source for decision makers and, ultimately, the AREIO's long-term sustainability. Appendix 2 outlines the ECO budget and management framework, which can serve as initial guidance.

As part of this study, a pilot, web-based observatory was set up for GMS and CAREC cases, and details on design, data, indicators and visual interface are given in Appendix 4. This is only a start, as many opportunities for further development loom. Almost limitless opportunities are laid out, based on global best practice, in Appendix 3. To realize such opportunities it will be necessary to use existing ICT infrastructure service provision in Asia. Such infrastructure needs to offer large bandwidth to handle large volumes of data transfer among AREIO clients and participants. It needs to offer extensive data storage and management capacities. It needs to provide sizable computing power because the AREIO service requires distributed and parallel computing capacity for stakeholders. Finally, the infrastructure service provision needs to include fine network capillarity across Asian regions to allow for interaction with data producer and user stakeholders. This includes also the requisite network and data management integrity, authentication and authorization service by the provider. Such a network service provider does exist now in Asia, with the Asia Pacific Advanced Network. How such an arrangement could be achieved, with ADB as initial AREIO host and content manager, and Asia Pacific Advanced Network as the infrastructure platform and service provider, is detailed in bullet points in Appendix 4.

With a full-fledged, sustainable AREIO, regional, national and local governments and decision makers can improve both their individual clusters and the way these clusters are connected as uniquely differentiated 
parts of global value chains. Here, the new activities would build on many existing policies but aim to overcome the traditional zero-sum competition between locations across Asia. Governments can make these choices in a more fact-based way, if the data provided has sufficient granularity for the border regions. This is a somewhat narrow but very practical application of the data that can open the doors to wider usage.

Geovisualization leverages geography as the basis for: interface design; user experience; display of data, attributes and relationships; scientific visualization; animation; and data compression. Together, they cast geography as the central mode of interaction with the regional GMS system. Geovisualization is particularly important for the purposes of the proposed observatory: (1) because of the significance of spatial attributes in providing unifying structure for the data; (2) because of the geographically disparate and heterogeneous nature of the likely data sources and users cases; (3) because of the significance of geography in providing context for the system and its use; and (4) because the system has a broad and likely growing set of users, it provides a common organization scheme.

All of the world's existing observatory systems noted in Table 2.3 rely on cartography as the main scheme for visualization and interaction. This is one form of geovisualization, although more could be done if ADB is to leverage the AREIO to enable and empower particular policy-making pathways and decision support systems atop its own unique user base, data, indicators, policy instruments, and strategies and goals for broadening participation - building on existing capacity and developing new capacity - and prioritizing activities. ADB is also relatively distinct from existing observatory platforms in its ambitions to dock the observatory with models, which will lend the observatory significant 'what-if' capabilities, which require special consideration.

The largest potential benefits would be derived from domestic upgrading of competitiveness and inclusion triggered by regional integration. A common data frame on underlying competitiveness can provide a useful facilitating device to establish groups of officials looking at the implications of this data, and at ways to improve the relevant policies. The way it is set up as proposed here would mean that full sovereignty over decision making with national governments would be retained, but it would enable them to learn from each other.

\section{NOTE}

1. Additional information can be found in the BSR Stars profile description in Appendix 2. 